Brit. F. vener. Dis. (1967), 43, 168.

\title{
IMMUNOFLUORESCENT ANTIBODY TECHNIQUE IN THE DIAGNOSIS OF GONORRHOEA BY DIRECT SMEARS FROM THE FEMALE*†
}

\author{
BY \\ J. M. D. GALLWEY, C. S. NICOL, AND M. RIDLEY \\ St. Thomas' Hospital, London
}

Fry and Wilkinson (1964) demonstrated that the fluorescent antibody (FA) technique was an additional sensitive means for the identification of $N$. gonorrhoeae in smears of secretion from patients. The purpose of this study was to evaluate the direct staining FA technique as part of a general busy clinic routine as opposed to a reference laboratory or research technique. For this purpose commercially available fluorescent conjugated antiserum was assessed and used.

The study was confined to female patients believed to have been at risk of infection. Diagnosis is often difficult by Gram-stained smears in these patients and a quicker answer than that provided by conventional cultural methods would be advantageous.

\section{Material and Methods \\ Optical Apparatus}

The apparatus for fluorescence microscopy was built in the hospital. The microscope was a standard monocular Watson Bactil 60 with a Beck dark-ground condenser having an adjustment for slide thickness. The ultra-violet light source was an HBO 200W high pressure mercury vapour lamp. The exciting filter was a Schott BG3, $4 \mathrm{~mm}$. in thickness, and the barrier filter used with the eyepiece was a Watson OY 12. The whole apparatus was set into an optical bench in a fairly dark area of the clinic laboratory.

\section{Antisera}

The rabbit anti-gonococcal serum conjugated with fluorescein isothiocyanate was obtained from Difco Laboratories. Each $5 \mathrm{ml}$. batch was tested against a series of organisms, including staphylococci of several phage types, Esch. coli of several types, $\alpha$-haemolytic streptococci, $P$. pyocyaneus, B. proteus, Streptococcus faecalis, Neisseria catarrhalis, and Neisseria meningitidis. Slight fluorescence was obtained with the Neisseria but with none of the other bacteria tested.

The Rhodamine-conjugated counterstain was also a product of Difco Laboratories. Mounting fluid and fluorescence-free immersion oil were obtained from Messrs. Gurr.

* Paper read to the MSSVD on March 25, 1966.

$\dagger$ Received for publication February 21, 1967.

\section{Preparation of FA Smears}

Each specimen was taken with a wire loop and spread very thinly without dilution within a circle engraved on a glass slide. Particular care was taken to obtain clean slides by washing in detergent, rinsing, and then keeping in alcohol until required. Dust and grease produced fluorescent background interference.

After drying in the air the smears were fixed with heat. The slides for FA examination from the urethra and cervix were taken at the first attendance only, at the same time as the routine smears and cultures were taken from the urethra, cervix, and rectum. Rectal slides were not considered for the FA technique as the background fluorescence was found to be poorly quenched and reading was therefore impossible.

The best results in staining with the Difco materials were obtained with each batch by diluting equal amounts of the anti-gonococcal conjugate with the Rhodamine conjugate diluted one in four with buffer. A negative control and a smear from a proved culture of $N$. gonorrhoeae was included with each group of slides stained.

After the minimum amount of staining material to cover the engraved circle had been added, the slide was incubated in a closed moist chamber at $37^{\circ} \mathrm{C}$. for 45 minutes.

The slides were washed in buffer for 10 minutes with one change, passed briefly through a gentle stream of distilled water to remove any buffer crystals, blotted gently, and dried in the air.

After mounting, the slides were viewed by darkground illumination under oil immersion using an ultra-violet light source. Gram-stained smears and cultures were made in the usual manner. Cultures were inoculated directly onto hydrocoele agar and incubated at $37^{\circ} \mathrm{C}$. for 48 hours before reading. Rectal cultures were inoculated onto a selective medium, a modification of the Thayer and Martin (1964) medium described by Scott and Stone (1966). When possible confirmatory fermentation reactions were performed on the $N$. gonorrhoeae isolated.

\section{Results}

The 61 patients studied were as far as possible consecutive patients attending the clinic as contacts of males with gonorrhoea, but were otherwise unselected; 54 ( 88.5 per cent.) were found positive by any method (Table I, opposite). 
TABLE I

FEMALE CONTACTS OF MALES WITH GONORRHOEA

\begin{tabular}{|c|c|c|c|}
\hline Female Patients & . & No. & Per cent \\
\hline $\begin{array}{l}\text { Positive by Any Method } \\
\text { Negative by Any Method }\end{array}$ & $\begin{array}{l}\ldots \\
\ldots\end{array}$ & $\begin{array}{r}54 \\
7\end{array}$ & $\begin{array}{l}88 \cdot 5 \\
11 \cdot 5\end{array}$ \\
\hline Total Patients Considered & .. & 61 & 100 \\
\hline
\end{tabular}

Table II shows the percentages of the total number found positive by FA, stained smear, and culture. In addition, one patient was found positive in rectal smears and culture but not elsewhere.

TABLE II

FEMALE PATIENTS FOUND TO BE POSITIVE IN URETHRA OR CERVIX

\begin{tabular}{|c|c|c|c|c|}
\hline Method & $\ldots$ & FA & $\underset{\text { Smear }}{\text { Gram-stained }}$ & Culture \\
\hline Positive & $\begin{array}{c}\text { No. } \\
\text { Per cent. }\end{array}$ & $\begin{array}{l}50 \\
82\end{array}$ & $\begin{array}{l}38 \\
62 \cdot 5\end{array}$ & $\begin{array}{l}41 \\
67\end{array}$ \\
\hline
\end{tabular}

Table III shows the number of positive sites found by each method. It is interesting to note the confirmation of the value of the rectal cultures. Twelve patients (22 per cent. of the positive cases or 19.5 per cent. of the total) showed positive cultures from the rectum, three of these $(5 \cdot 5$ per cent. of the positive cases) not being found in the Gram-stained smears.

TABLE III

SITES OF POSITIVE FINDINGS

\begin{tabular}{|c|c|c|c|c|}
\hline Method & .. & FA & $\begin{array}{c}\text { Gram-stained } \\
\text { Smear }\end{array}$ & Culture \\
\hline Site & $\begin{array}{l}\text { Urethra } \\
\text { Cervix } \\
\text { Rectum }\end{array}$ & $\begin{array}{l}41 \\
48 \\
-\end{array}$ & $\begin{array}{r}19 \\
34 \\
9\end{array}$ & $\begin{array}{l}32 \\
41 \\
12\end{array}$ \\
\hline
\end{tabular}

Table IV shows that seven patients were found positive by the FA method alone. Three of them showed other corroborative evidence with positive Gram-stained smears or cultures at a later date, but there was no supporting evidence in the others.

TABLE IV

POSITIVE AND NEGATIVE FINDINGS BY METHOD AND SITE

\begin{tabular}{|c|c|c|c|}
\hline $\begin{array}{l}\text { No. of } \\
\text { Patients }\end{array}$ & Urethra and/or Cervix & \multicolumn{2}{|c|}{ Urethra, Cervix, and/or Rectum } \\
\hline 10 & FA + ve & Gram-stained Smear & - ve \\
\hline 12 & $\mathrm{FA}+\mathrm{ve}$ & Culture & $-\mathrm{ve}$ \\
\hline 7 & $\mathrm{FA}+\mathrm{ve}$ & $\begin{array}{l}\text { Gram-stained Smear } \\
\text { and Culture }\end{array}$ & - ve \\
\hline 2 & FA - ve & Gram-stained Smear & $+\mathrm{ve}$ \\
\hline 3 & FA - ve & Culture & + ve \\
\hline
\end{tabular}

Discussion

The technique as described by Wilkinson and Fry (1964) provides adequate masking of the autofluorescence of the vaginal secretions and the pus cells so that the green fluorescing gonococci can be picked out against the orange background. If, however, films are not spread thinly, background fluorescence may not be completely quenched.

Time and available facilities in general clinics do not usually allow for the preparation and testing of fluorescent sera and commercial preparations must be relied upon. The commercial sera used in this study appeared to be consistent from batch to batch both as regards fluorescent strength and specificity.

The direct FA method provides a reasonably rapid answer and is a very sensitive method for the detection of $N$. gonorrhoeae.

It is clearly a much more expensive and tedious process than simple Gram-staining and is probably best retained for those patients whose history suggests that they have been at real risk yet in whom simple staining fails to reveal the gonococcus.

\section{Summary}

Immunofluorescence tests, using a commercially prepared anti-gonococcal serum conjugated with fluorescein isothiocyanate, were performed on smears from the genital tracts of 61 female patients attending a special treatment clinic as contacts of males with gonorrhoea. The method was shown to be more sensitive than conventional staining techniques or cultures.

Our thanks are due to St. Thomas' Hospital Endowment Fund for a grant making this work possible, and to $\mathrm{Mr} \mathrm{A}$. Stone for his help with the slides and cultures.

\section{REFERENCES}

Fry, C. S., and Wilkinson, A. E. (1964). Brit. F. vener. Dis., 40, 125.

Scott, J., and Stone, A. H. (1966). Ibid., 42, 103.

Thayer, J. D., and Martin, J. E. (1964). Publ. Hlth Rep. (Wash.), 79, 49.

La technique immunofluorescente des anticorps dans le diagnostic de la blennorragie par des frottis pris des femmes malades

\section{RÉSUMÉ}

Des tests immunofluorescents, se servant d'un sérum anti-blennorragique conjugué à fluorescéine isothiocyanate préparé commercialement ont été faits sur des frottis provenant des voies génitales de 61 patientes visitant un dispensaire où un traitement spécial est donné aux contacts des hommes atteints de blennorragie. Il a été demontré que cette méthode est plus sensible que la technique courante des colorants ou celle des cultures. 